\title{
Rotator Cuff Syndrome and Current Approaches in Treatment
}

\section{Rotator Manşet Sendromu ve Tedavide Güncel Yaklaşımlar}

\author{
(D) Demet TERZi1 ${ }^{1}$, (D) Ali ZEYBEK ${ }^{2}$ \\ ${ }^{1}$ Tekirdağ Namık Kemal University Institute of Health Sciences, Department of Anatomy, Tekirdağ, Turkey \\ ${ }^{2}$ Tekirdağ Namık Kemal University Faculty of Medicine, Department of Anatomy, Tekirdağ, Turkey
}

\begin{abstract}
Rotator cuff syndrome is a common health problem causing serious physical, psychological and material losses. Since the treatment process is long and difficult and the treatment costs are increasing, a lot of research is done especially on risk factors. Both intrinsic and extrinsic factors are among the underlying causes. Although some of these factors could be changed, most of them are unchangeable factors due to anatomical structure and functions. Therefore, it is very important to determine these factors in advance and apply preventive treatments. In this study, it is reviewed to give information about the studies on rotator cuff syndrome risk factors and treatment approaches.
\end{abstract}

Keywords: Rotator cuff, acromion, subacromial space

\section{Öz}

Rotator manşet sendromu önemli fiziksel, psikolojik sorunlara ve ekonomik kayıplara sebebiyet veren, sık karşılaşılan bir sağlık problemidir. Tedavi sürecinin uzun ve zorlu olması ve tedavi maliyetlerinin de gittikçe artması nedeniyle özellikle risk faktörleri konusunda oldukça fazla araştırma yapılmaktadır. Altında yatan sebepler içinde hem intrinsik hem ekstrinsik faktörler bulunmaktadır. Bu faktörlerden bir kısmı değiştirilebilir olsa da çoğu anatomik yapı ve fonksiyonlara bağlı değiştirilemeyen faktörlerdir. Bu nedenle bu faktörlerin önceden belirlenmesi ve koruyucu tedavilerin uygulanması oldukça önemlidir. Bu çalışma rotator manşet sendromu risk faktörleri ve tedavi yaklaşımları üzerine yapılan çalışmalar hakkında bilgi vermek amacıyla derlenmiştir.

Anahtar Kelimeler: Rotator manşet, akromion, subakromial boşluk

\section{INTRODUCTION}

Rotator cuff syndrome is one of the most common causes of shoulder pain and loss of functionality, which can develop due to many intrinsic or extrinsic reasons and mostly occur due to compression of the musculus (m.) subscapularis, $m$. supraspinatus, $\mathrm{m}$. infraspinatus and $\mathrm{m}$. teres minor, which are commonly referred as rotator cuff muscles, in the subacromial space or due to their tearing for some reason ${ }^{1,2}$.

Patients with rotator cuff tears have a reduction in their quality of life equivalent to those with congestive heart failure, diabetes, myocardial infarction or depression ${ }^{3}$. Therefore, determining potential risk factors for the development of rotator cuff pathologies has been chosen as a subject for more studies in recent years.
In addition to reduced quality of life, treatment costs are increasing rapidly for patients with rotator cuff pathology. Pre-operative and outpatient costs can range from \$5,500 to 11,000 , excluding rotator cuff repair, follow-up, care, and post-operative physical therapy ${ }^{4}$. In addition to affecting health, loss of function and psychological problems, it causes significant economic losses. Therefore, rotator cuff syndrome is a clinically important picture that should be emphasized. In this study, it was aimed to examine rotator cuff syndrome and its treatment approaches.

\section{Rotator Cuff Biomechanics}

When the rotator cuff muscles, which are independent from each other, reach the end point, they mix with the fibers of the adjacent tendons and adhere to the humerus. It is very 
difficult to distinguish the effects that occur during their individual contractions, since they also affect the end point of the neighboring muscle during contraction ${ }^{5}$.

There is a concept of force couple in rotator cuff biomechanics. The force couples are expressed as two opposite forces that help to rotate an object. In the studies, in terms of the shoulder joint, it has been reported that rotator cuff muscles form force couple with $\mathrm{m}$. deltoideus in the coronal plane and $\mathrm{m}$. subscapularis forms force couples with $\mathrm{m}$. infraspinatus and $\mathrm{m}$. teres minor in the transverse plane $e^{6,7}$.

For a smooth shoulder abduction in the coronal plane, contraction with balanced force is needed between $\mathrm{m}$. deltoideus and $\mathrm{m}$. infraspinatus, $\mathrm{m}$. teres minor and $\mathrm{m}$. subscapularis. In cases where $m$. deltoideus is much stronger, $\mathrm{m}$. latissimus dorsi and $\mathrm{m}$. pectoralis major muscles also help the rotator cuff muscles. In the transverse plane, in order to keep the head of humerus in cavitas glenoidalis, the balance between $\mathrm{m}$. infraspinatus and $\mathrm{m}$. teres minor and $\mathrm{m}$. subscapularis is important. Anterior or posterior dislocations can be seen in the force differences that may occur in the transverse plane?

Another situation that is anatomically and biomechanically important is the cable-crescent model formed by $\mathrm{m}$. supraspinatus, $\mathrm{m}$. infraspinatus and $\mathrm{m}$. teres minor muscles at the points of attachment to the tuberculum majus. Before these muscles become tendon at the end points, they stretch in the form of a cable and then become thinner by forming a crescent-shaped structure and cover the tuberculum majus. The cable acts as a suspension, reducing the load while transferring it to the avascular thin crescent-shaped structure. This is a protective mechanism to prevent tear ${ }^{8}$.

\section{Formation Mechanism and Causes of Rotator Cuff Tears}

Rotator cuff muscles, which we use frequently during daily activities, are exposed to many factors including traction, pressure, contusion, inflammation, and more importantly, degenerative changes due to aging because of some reasons such as subacromial loading and regional changes in blood supply. These factors change the normal biological structures of tissues by causing tendinitis over time. M. supraspinatus tendon is affected from this situation most commonly9. As a result of the changes occurring in the subacromial bursa that is affected secondarily, the subacromial region becomes narrower. With shoulder elevation movements, the tendons of the rotator cuff muscles are squeezed between the humerus head and the coracoacromial arch. If this situation continues, the destructive effects on the tendons may increase and cause tears ${ }^{10}$.

Although there are many different views on the mechanism of rotator cuff tears, intrinsic and extrinsic factors are emphasized. Intrinsic causes include disorders in the vascular supply of the tendon, smoking, cholesterol, aging, and microstructural collagen fiber abnormalities.

The vascular supply of the rotator cuff muscles begins to decrease especially at the age of forty years and over, the amount of fibrocartilage decreases in the tendon adhesion areas, vascularity deteriorates, cellular losses increase, tendon disintegration and separation in Sharpey fibers at the tendonbone junction are seen. With the decrease in mobility at an advanced age, the possibility of tears in the tendons increases even with less force ${ }^{11}$.

Lohr and Uhthoff' ${ }^{12}$ reported that rotator cuff blood supply was better on the bursal side, but less on the humeral side. However, Kim et al..$^{13}$ argued in their study that bursal sided rotator cuff tears were the most common partial tears, and they explained the reason as exposure of the anteromedial part of rotator cuff tendon and the acromion to repetitive trauma. Although it has been suggested that insufficient blood supply causes more degeneration in tendons and the formation of tears, the role of hypovascularity in tear formation is still not fully elucidated ${ }^{12,13}$. According to the results of a study conducted in 2010, it was observed that low density lipoprotein value was high in people with rotator cuff tears, while high density lipoprotein value remained at low levels, and it was reported that cholesterol level could be considered a risk factor in the formation of tears ${ }^{14}$.

Extrinsic causes are factors related to the bone or soft tissue around the rotator cuff, which may cause tendon tears by narrowing the subacromial space. The subacromial space is the space between the coracoacromial arch, the anterior part of the acromion and the head of humerus. In publications on the subacromial space and rotator cuff, it is stated that conditions such as the acromion type, the shape of the anterior acromial spur, the acromial index, the features related to the coracoacromial ligament, the angle of the coracoid inclination, and the angle of the coracoacromial arch are associated with the formation of tears.

When we consider the acromion type, it is known that there are 4 types of acromion: flat type, curved type, hooked type and convex type. In the meta-analysis conducted by Morelli et al. ${ }^{15}$, they stated that people with type 3 acromion had three times more rotator cuff tears than those with type 1 or type 2 acromion. According to another study, type 3 acromion causes subacromial compression by significantly narrowing the subacromial distance compared to type 1 or type 4 acromion $^{16}$. However, another study does not support these findings and states that having a type 3 acromion does not pose a higher risk of rotator cuff tear than other acromion types ${ }^{13}$. The acromion inclination angle is found by measuring the angle between the lines formed by the intersection of the line passing through 
the front and rear ends of the acromion at the highest point of the curvature. The angle of the acromion anterior inclination is much more effective than the acromion type in the formation of rotator cuff tears. Increasing this angle increases the angle of the coracoacromial arch and narrows the subacromial space $^{17}$.

Another aspect that supports the tear formation is the length of the anterior acromial spur. The anterior acromial spurs are grouped as small if they are less than $5 \mathrm{~mm}$, medium if they are between 5-10 $\mathrm{mm}$, and large if they are more than $10 \mathrm{~mm}$ according to their lengths. Considering their shapes, they can be grouped as straight and curved ${ }^{18}$. The larger the spur, the greater the likelihood of acromial inclination angle and the formation of rotator cuff tear. Spur size and acromial inclination angle increase with age ${ }^{17}$.

Balke et al. ${ }^{19}$ defined the acromial index as the ratio of the glenoid-acromion lateral edge distance to the glenoid-humeral lateral edge distance. Individuals with a large acromial index are more likely to have rotator cuff tears. This may be because of higher orientation of the head of humerus in the acromion and coracoacromial arch due to the force vector of the $\mathrm{m}$. deltoideus. In individuals with larger acromial indices, the muscles may not function optimally and the humeral head may not be held in a centered position. This may reduce the subacromial area and cause compression of the rotator cuff tendons passing through it ${ }^{15}$.

Coracoid inclination angle is the angle formed between the line drawn from the proc. coracoideus anterior cortex and the line drawn tangent to the glenoid surface from front to back. The reduction of this angle increases the angle of the coracoacromial arch, narrows the subacromial space and creates a risk for tear formation ${ }^{20}$.

\section{Treatment Approaches to Rotator Cuff Syndrome}

Although written sources about the rotator cuff concept have been available since the $18^{\text {th }}$ century, current approaches started to emerge mostly in the $20^{\text {th }}$ century. The first rotator cuff repair in the world was performed by Coddman in $1909^{21}$. In 1944, Moseley classified tears and described the surgical treatment in detail. In 1972, Neer first described it using the term "impingement syndrome" and attributed the tear formation to mechanical compression under the coracoacromial arch at a rate of 95\%. With anterior acromioplasty, he expanded the exit area of $\mathrm{m}$. supraspinatus, smoothed the bone surface under the acromion and successfully repaired by reducing friction.

The treatment process for rotator cuff tears can be planned in two different ways. The decision of choosing a treatment is affected by some conditions such as the shape, location, and depth of the tear, the age range of the individual, his/ her background and the level of recovery he/she expects to reach after treatment. Surgery is preferred for individuals with high activity levels or athletes, especially in younger ages and people with acute injuries. And, conservative treatment is preferred in a chronic picture ${ }^{22}$.

\section{Conservative Treatment}

Neer states that the basis of conservative treatment is resting during exacerbation of symptoms, and a correct exercise program when symptoms disappear. The first aim is to reduce subacromial inflammation, prepare the ground for healing and restore functionality.

Exercise practices should aim at strengthening $\mathrm{m}$. infraspinatus, $\mathrm{m}$. teres minor and $\mathrm{m}$. subscapularis, which are the muscles depressing the humeral head without increasing the dominance of $\mathrm{m}$. deltoideus, and $\mathrm{m}$. trapezius, $\mathrm{m}$. levator scapulae and $\mathrm{m}$. serratus anterior, which causes elevation of scapula ${ }^{23}$.

Conservative treatment principles generally consist of protection, medical treatment, physiotherapy and rehabilitation stages. During the protection phase, it is recommended to rest by avoiding overhead activities that will cause compression in the rotator cuff muscles and subacromial bursa. If the pain is disturbing in daily life activities and is aggravated by movement, a shoulder brace may be preferred. The rest period should be kept as short as possible.

In medical treatment, non-steroidal anti-inflammatory drugs and steroid injection into the subacromial area reduce pain and allow exercise. However, it is not recommended after 2-3 repetitions because of damage to the tendon ${ }^{24}$. In recent years, it has been observed that platelet rich plasma (PRP) applications have a rapid and significant healing effect in rotator cuff cases, especially at the early stage. The plasma injected in PRP application is enriched in platelets and contains various proteins that support cell growth. In studies comparing corticosteroid injection with PRP application, it was found that PRP application in the early period was more effective, but the two methods were not superior to each other in the long term ${ }^{25}$.

Physiotherapy and rehabilitation include training the individual about conditions and movement components that increase symptoms, physical modalities to reduce or heal symptoms, strengthening and stretching exercises for muscle strength deficiencies due to pain or weakness or muscle shortness, joint mobilization techniques, functionality or work- occupational activities. The goal is to reach normal range of motion, reduce pain and restore normal scapula-thoracic rhythm ${ }^{26}$. Due to the high probability of contracture formation, the sooner a personalized exercise program is applied, the faster the targeted and most effective results are achieved. 
Neuromuscular control is also affected in the presence of unbalances between the forces related to the shoulder joint and related stability problems. Proprioceptive training plays an important role in the conservative treatment of this condition. Proprioceptive training ensures that the shoulder is protected and guided by appropriate muscle activity by sending returns to the central nervous system by the musculoskeletal system. Proprioceptive rehabilitation is at the forefront in increasing cognitive awareness related to position, movement and stabilization ${ }^{27}$.

Strengthening the stabilizer muscles of the shoulder is a very effective method in treatment. Exercises known as closed kinetic chain exercises include movements that increase normal functions of the muscles that work systematically in a certain order. In a study conducted in 2007, the effects of open and closed kinetic chain exercises on problems with the rotator cuff were investigated and compared. In the study, it was stated that in exercises to be performed to strengthen the muscles stabilizing the shoulder circumference and scapula, it was more effective to continue with open kinetic chain exercises after the work done using closed kinetic chain exercises first, but the two types of exercises did not have superiority to each other ${ }^{28}$.

\section{Surgical Treatment}

Individuals with acute traumatic rotator cuff tears require surgical repair in the first weeks after injury. In order to achieve more positive results in surgical application in fullthickness tears, it should be early stage and there should be no degeneration in the tissues ${ }^{28}$. While the success of surgery is higher in those who have not had previous injuries and at a young age, the prognosis is worse in elderly individuals and in long-term tears accompanied by loss of strength. Surgery should be considered as the primary treatment in young individuals with a rotator cuff tear or tuberculum majus displaced avulsion fracture following an acute trauma found radiological imaging methods, and as the secondary treatment in individuals who have received conservative treatment for six weeks or more but have not achieved results ${ }^{29}$. Nowadays, the success rate of rotator cuff surgeries is increasing with the trial of new devices and repair methods. For treatment, an arthroscopic-assisted mini-open repair has been observed instead of an open surgical method, and a change towards a full arthroscopic method has recently been observed due to the advantage of its being less invasive ${ }^{30}$. While open surgery is preferred as the gold standard in massive tears, the arthroscopic method is more preferred in small and medium-sized tears ${ }^{31}$. Although there are advantages such as preservation of m.deltoideus insertion, less soft tissue incision, less pain and rapid return to functionality in the full arthroscopic method, it is also stated that bone-tendon fixation with full arthroscopic technique is weaker, it takes a long time to learn the technique, and it should be performed by experienced surgeons in case of possible complications ${ }^{21,32}$.

Within arthroscopic methods, there are differences between full arthroscopy and mini open repair. While deciding between the two, if the patient's shoulder range of motion and muscle strength are better, but there is a surgical indication with pain, the full arthroscopic method is preferred. However, the mini open method is preferred in cases where the loss of strength is more important and the tear needs to be repaired more securely.

Bone or suture anchors are implants that are used in tendon therapy and connect tissue and bone, and they are frequently used in rotator cuff surgery. When determining the technique to be preferred in surgery, it is important that the bone tissue has the strength to hold the anchors. Conditions such as the long duration of the tear, the advanced age of the patient, and some metabolic diseases can affect the bone density and prevent anchor placement. In such cases, repair may be required through open surgery using bone tunnels. However, there is information showing that anchors have more holding abilities than bone tunnels ${ }^{33}$.

Moosmayer et al..$^{34}$ evaluated the effect of physiotherapy with open or arthroscopic-assisted mini-open method in patients with symptomatic, full-thickness tears not exceeding $3 \mathrm{~cm}$, as a result of a 10-year follow-up, and they stated that surgical treatment had more permanent and significant effects in functionality and pain scores compared to physiotherapy treatment in the long term. They reported that they have effects. Although physiotherapy alone provides improvement in the short term, it is thought that it causes complaints again in the long term. Therefore, physiotherapy is thought to be a more effective treatment after a successful surgery.

\section{CONCLUSION}

Rotator cuff syndrome is one of the most common causes of shoulder pain, which can cause significant losses in quality of life, requires a multi-component and demanding treatment program, and is in the third place in terms of incidence after back and neck pain. Conservative or surgical treatment processes are both difficult and expensive. For this reason, it is especially important to determine risk factors, to take precautions and to apply preventive treatment methods. Although there are studies showing that there are various risk factors, rotator cuff syndrome risks are an important issue that needs to be studied and clarified in order to explain the situations that are still not agreed or proven.

\section{Ethics}

Peer-review: Externally peer-reviewed. 


\section{Authorship Contributions}

Concept: D.T., A.Z., Analysis or Interpretation: D.T., A.Z., Literature Search: D.T., A.Z., Writing: D.T., A.Z.

Conflict of Interest: No conflict of interest was declared by the authors.

Financial Disclosure: The authors declared that this study received no financial support.

\section{References}

1. Leblebici B, Adam M, Yapgu S, Bagis S, Akman MN. Rotator Manşon Problemlerinde Açık ve Kapalı Kinetik Zincir Skapulohumeral Stabilite Egzersizlerinin Karşılaştırılması. Türk Fiz Tıp Rehab Derg. 2007;53:134-7.

2. Ozkan S, Adanas C. Omuz İmpingement Sendromu ve Rotator Cuff Cerrahisinde Orta Dönem Sonuçları. Van Sag Bil Derg. 2018;11:11-4.

3. Smith MA, Smith WT. Rotator cuff tears: an overview. Orthop Nurs. 2010;29:319-22.

4. Yeranosian MG, Terrell RD, Wang JC, McAllister DR, Petrigliano FA. The costs associated with the evaluation of rotator cuff tears before surgical repair. J Shoulder Elbow Surg. 2013;22:1662-6.

5. Soslowsky U, Carpenter JE, Bucchieri JS, Flatow EL. Biomechanics of the rotator cuff. Orthop Clin North Am. 1997;28:17-30.

6. Saha AK. The classic. Mechanism of shoulder movements and a plea for the recognition of "zero position" of glenohumeral joint. Clin Orthop Relat Res. 1983;3-10.

7. Parsons IM, Apreleva M, Fu FH, Woo SL. The effect of rotator cuff tears on reaction forces at the glenohumeral joint. J Orthop Res. 2002;20:439-46.

8. Mahirogulları M, İsyar M, Cakmak S. Rotator Manşet Yırtıkları. TOTBíD Derg. 2013;12:353-9.

9. Akpınar S, Özkoc G, Cesur N. Rotator Manşet Anatomisi, Biyomekaniği ve Fizyopatolojisi. Acta Orthop Traumatol Turc. 2003;37:4-12.

10. Hawkins RJ, Abrams JS. Impingement syndrome in the absence of rotator cuff tear (stages 1 and 2). Orthop Clin North Am. 1987;18:373-82.

11. Matsen FA, Arntz CT, Lippitt SB. Rotator Cuff, The Shoulder. Philadelphia: WB Saunders, 1998. p. 755-839.

12. Lohr JF, Uhthoff HK. The microvascular pattern of the supraspinatus tendon. Clin Orthop Relat Res. 1990;254:35-8.

13. Kim HJ, Kim JY, Kee YM, Rhee YG. Bursal-Sided Rotator Cuff Tears: Simple Versus Everted Type. Am J Sports Med. 2018;46:441-8.

14. Abboud JA, Kim JS. The effect of hypercholesterolemia on rotator cuff disease. Clin Orthop Relat Res. 2010;468:1493-7.

15. Morelli KM, Martin BR, Charakla FH, Durmisevic A, Warren GL. Acromion morphology and prevalence of rotator cuff tear: A systematic review and meta-analysis. Clin Anat. 2019;32:122-30.

16. Duymus M, Asal N, Bozkurt A, Orman G, Yesilkaya Y, Yılmaz Ö. Semptomatik Hastalarda Akromion Tiplerinin Dağılımı ve Subakromiyal Mesafeler;MRG Bulguları. Kafkas J Med Sci. 2012;2:60-5.

17. Alraddadi A, Alashkham A, Lamb C, Soames R. Examining changes in acromial morphology in relation to spurs at the anterior edge of acromion. Surg Radiol Anat. 2019;41:409-14.
18. Toivonen DA, Tuite MJ, Orwin JF. Acromial structure and tears of the rotator cuff. J Shoulder Elbow Surg. 1995;4:376-83.

19. Balke M, Schmidt C, Dedy N, Banerjee M, Bouillon B, Liem D. Correlation of acromial morphology with impingement syndrome and rotator cuff tears. Acta Orthop. 2013;84:178-83.

20. Asal N. Rotator Manşet Yırtıklarında MRG ile Korakoid İnklinasyon Açısı ve Korakoakromial Ark Açııının Değerlendirilmesi. Kırıkkale Üniversitesi Tıp Fakültesi Dergisi. 2019;21:167-72.

21. Yamaguchi K, Levine WN, Marra G, Galatz LM, Klepps S, Flatow EL. Transitioning to arthroscopic rotator cuff repair: the pros and cons. Instr Course Lect. 2003;52:81-92.

22. Lähteenmäki HE, Virolainen P, Hiltunen $A$, Heikkilä J, Nelimarkka Ol. Results of early operative treatment of rotator cuff tears with acute symptoms. J Shoulder Elbow Surg. 2006;15:148-53.

23. Ainsworth R, Lewis JS. Exercise therapy for the conservative management of full thickness tears of the rotator cuff: a systematic review. Br J Sports Med. 2007:41:200-10.

24. Matthews TJ, Hand GC, Rees JL, Athanasou NA, Carr AJ. Pathology of the torn rotator cuff tendon. Reduction in potential for repair as tear size increases. J Bone Joint Surg Br. 2006;88:489-95.

25. Subası V. Rotator Kaf Tendon Patolojilerinde Ultrasonografi Rehberliğinde Uygulanan Plateletten Zengin Plazma ve Kortizon Enjeksiyonlarının Karşılaştırılması. Turk J Osteoporos. 2019;25:43-8.

26. Dursun H, Özgül A. Tedavi Edici Egzersizler. İçinde: Oğuz H, Dursun E, Dursun N, Tibbi Rehabilitasyon. İstanbul: Nobel Kitabevi, 2004;491-526.

27. Michener LA, Walsworth MK, Burnet EN. Effectiveness of rehabilitation for patients with subacromial impingement syndrome: a systematic review. $J$ Hand Ther. 2004;17:152-64.

28. Chebli C, Matsen FA. Rotator-Kalp Yetmezliği ve Tedavi. Current Opinion in Orthopaedics. 2006;1:172-9.

29. Çapkın FS. Rotator Manset Sendromu Olan Bireylerde Proprioseptif Egzersizlerin Etkinliği, Haliç Üniversitesi Sağlık Bilimleri Enstitüsü Fizyoterapi ve Rehabilitasyon Anabilim Dalı. Yüksek Lisans Tezi 2019; İstanbul.

30. Güven 0. "Mini-Open" Küçük İnsizyondan Rotator Manşet Tamiri. Turkiye Klinikleri J Surg Med Sci. 2007;3:7-9.

31. Massoud SN, Levy O, Copeland SA. Subacromial decompression. Treatment for small- and medium-sized tears of the rotator cuff. J Bone Joint Surg Br. 2002;84:955-60.

32. Celik H, Seckin MF, Akman S. Rotator Manşet Cerrahisinde Komplikasyonlar. Okmeydanı Tıp Dergisi. 2017;33:155-63.

33. Reed SC, Glossop N, Ogilvie-Harris DJ. Full-thickness rotator cuff tears. A biomechanical comparison of suture versus bone anchor techniques. Am J Sports Med. 1996;24:46-8.

34. Moosmayer S, Lund G, Seljom US, Haldorsen B, Svege IC, Hennig T, et al. At a 10-Year Follow-up, Tendon Repair Is Superior to Physiotherapy in the Treatment of Small and Medium-Sized Rotator Cuff Tears. J Bone Joint Surg Am. 2019;101:1050-60. 